\title{
Female visibility through Korean \\ literature: Feminist theological critique ${ }^{1}$
}

\author{
Eun Ok Jeong \& Yolanda Dreyer \\ Department of Practical Theology \\ University of Pretoria
}

\begin{abstract}
This article introduces Korean women's experience as seen through the lense of social and cultural backgrounds, from the premodern through to the postmodern era. Korean literature is used as a source to investigate Korean women's experiences and perspectives. By means of feminist critique this article explores men-centered influences in Korean literature. It aims to illustrate the importance of the issue of female visibility through Korean literature from a Korean woman's perspective. Two texts are analyzed and critiqued: the first is the myth of Korean origin. The second is a story of Gasi Gogi (a thorny fish). The article is intended to stimulate debate on gender, voices, and authority from a feminist perspective, in order to transcend the more traditional interpretations.
\end{abstract}

\section{INTRODUCTION}

This article introduces Korean women's experience as seen through the lenses of social and cultural backgrounds from the premodern through to the postmodern era. In premodern times Korean women were marginalized in society. As the world changed from premodern to modern to postmodern, the position of Korean women changed and has improved. The aim of this article is to describe the present reality of Korean women and explain how they have created an identity for themselves. Korean women have partaken in the entire Korean history

\footnotetext{
1 This article is based on Eunok Jeong's Ph D dissertation, entitled "Empowerment of Korean women from a feminist perspective: A postmodern hermeneutical study". The dissertation was under the supervision of Prof Dr Yolanda Dreyer, Faculty of Theology, University of Pretoria (2002).
} 
alongside the men, but women have also had their own specific experiences due to their position in society.

Korean literature is used as a source for investigating Korean woman's experiences and perspectives. By means of feminist critique this article explores men-centered influences in Korean literature. Patriarchal tendencies are exposed. The aim is to illustrate the importance of the issue of female visibility through Korean literature from a Korean woman's perspective. Two texts will by analyzed and critiqued: the first is the myth of Korean origin, which is an ancient novel. The second is a story of Gasi Gogi (A thorny fish) which has been influenced by postmodern thinking. The intention is to stimulate debate concerning gender, voices, and authority from a feminist perspective, in order to transcend the more traditional interpretations. From Korean literature positive and liberating possibilities for new ways of thinking and for contributing to building up the confidence and agency of Korean women, are indicated.

\section{WOMEN'S EXPERIENCE}

Women experience the world differently from men: biologically, politically, socially, culturally and religiously. Despite the differences in cultures and societies, women's oppression occurs everywhere in patriarchal societies, and is reinforced by patriarchal religion (Heine 1988:4). Women are invisible, nameless, worthless, and inferior in patriarchy. Destructive patterns of domination and violence threaten not only women but also all humans, and the planet itself. Sharma (1994:329) suggests, "women need to exorcise the andocentric model of humanity from their consciousness and replace it thoroughly and completely, once and for all, with an androgynous model of humanity". The gendering of social life comes from patriarchal and andocentric ideologies. Korean women have been taught subordination in the Korean patriarchal churches and society. Lisa Isherwood and Dorothea McEwan (2001:75) point out that, "faith is not an act of obedience without growth of one's own power". Women strive to overcome the barriers put up by patriarchal ideologies in the contemporary world and in the church. 


\subsection{Korean women's experience}

The premodern era in Korea was dominated by a patriarchal mind-set. Korean patriarchy was institutionalized by the "kingship system" which was the politicolegal institution recognized by the Lee dynasty, and was supported spiritually by Confucianism since 1394. "Patriarchy" literally means "rule of the father". Patriarchy is the sanctuary of male authority over females and younger people. For five hundred years, male dominated societies have accepted patriarchy as a "natural order": women should serve men and children should serve their parents. Because they are the ones with the weaker minds, they should serve the stronger. Here, subordination is linked with inferiority. The authority of men is based on superiority. Patriarchy creates a specific order among people and also controls the economy and politics in society.

In traditional Korean society women were largely confined to the home. From a young age, women were required to internalize the Confucian virtues of subordination and endurance in order to be prepared for their future roles of wife and mother. While being denied any opportunity to participate in the management of the large extended family, women nevertheless played an important role in the family. They helped to maintain the family line. Women were invisible, voiceless, nameless, and were treated as secondary in the premodern era. Women were not allowed to work in public places. They dedicated themselves to their families as beloved wives, respected mothers and hard workers. Women were unable to obtain any rights in the family and in society. They were invisible. Women were not allowed to speak or be heard in society or in their family. Women did not have the right to express their feelings. They were voiceless. When a baby girl was born, the parents were not happy, because they needed men for agricultural labour. After marriage, women lost their names. They were either called somebody's wife, somebody's mother or somebody's family member. Nobody remembered women's names. Even women themselves did not want to be called by their official names. Women were nameless. Women were barred from studying at public educational 
institutions. They were marginalized from politics, economy, culture and even religion. Women were victims.

During the time of Japanese colonialism (1910-1945), Korea entered the modern era. The country was depleted because the Japanese exploited its resources. After that everything was further destroyed in the Korean Civil War (1950-1953). During Japanese colonialism many Korean women were forced to serve Japanese armies as "comfort women". The Japanese took two hundred thousand young women to the battlefield as "comfort women". Fifty to seventy thousand of them became prostitutes for Japanese soldiers (Lee HS 1992:388389; see Ahn SY 1992:345-353). They were between 16 and 32 years old (Lee HS 1992: 388). This was nothing short of forced prostitution: Japanese soldiers in World War II were "served" by Korean women. The Korean government regarded this as shameful and immoral. As a result, the facts were not officially divulged until 1992. When the Japanese lost the war, many of the comfort women were killed. Some women remained in Japan and a small number returned to Korea. They were treated as sinners and shameful persons. This means that they were both exploited by Japanese colonization and rejected by their own people.

Up to the 1970s Korea experienced widespread poverty. The people desired to be become rich as individuals and as a nation. Therefore women went to work. They were to contribute to the economic and industrial growth of the country. Though this marked an improvement in the situation of women, they were severely discriminated against in the workplace. They received low wages, suffered poor working conditions and long working hours. Always they were treated as inferior to their male workers. They still mostly endured their bad conditions silently just as they had endured the traditional structures of the premodern era.

Today the life-style of Korean society is not very different from that of North America or any other western countries. There is evidence of postmodern trends in Korea. Western capitalism and its motto of "pursuit of profits" and "convenience" have affected Korean society (Kim AY 1995:227). Westernization 
in Korea began when the people were disillusioned by a declining labour market. When international socialism collapsed, Korea adopted western capitalism. The American economic system and politics are intertwined with the politics and economies of the world. This does not make much allowance for pluralism in the world, with the possible exception of cultural plurality. Even though postmodern thinking emphasizes the variety of lives, rhythms, theories, sounds, colours and opinions, economic reality does not reflect this view of variety. The world succumbs to a kind of fascism dictated by the American politics and economic system.

Even in this new context Confucian ethics and views on the world remain imprinted on all facets of Korean society. Korean Christians are also not completely free from Confucian thought. Christianity represents western culture, which is individualistic. East Asian cultures are Confucian: family and family ties are strongly emphasized. When Kim Jung Ha (1996:349) refers to AsianAmerican women she states that "Confucianism indicates an apparent stability and coherence of Asian-American families".

However, this does not come without a high price, which is paid by AsianAmerican women in particular. In Confucianism the notion of "family" is the basis of all human relations. The authority of the father, who is the head of the family, is important for guarding the security and harmony of the family. It follows then that male superiority and female subordination will be considered necessary in such a system. The Confucian notion of family is the foundation of the Korean educational system, religious institutions, political structures and even personal relations in Korean society. Thus, today, Korean women need to analyze and deconstruct patriarchal values which uphold the system of inequality. Through analysis and deconstruction Korean women will be able to improve not only their social position, but also change the structures of society from their roots.

Korean feminist theology began in Korea in the 1970's. The aim was the establishment of human rights and resistance against political dictatorship (196070). In the early 1980s feminist theology blossomed in Korea. Some foreign feminist books (cf Ruether 1979, 1985; Russell 1982, 1985; Trible 1984; 
Schüssler Fiorenza 1981) were translated into Korean and Korean women wrote many feminist books themselves (Lee OJ 1983, 1985, 1987, 1988; Kim YO 1988; Lee ES 1989, 1991; Lee HS 1992; Lim HS 1991; Choi MJ 1987, 1990, 1991, 1995; Chung HK 1990), sharing their own experiences. Issues dealt with were: How can women understand a male God (Ruether 1992)? What are the female characteristics of God (Moltmann \& Moltmann-Wendel 1991)? What is the image of Jesus Christ from the perspective of the Korean women (Chung H K 1990)? What are feminist theologians' opinions of the Korean situation (Park S K 1983)? Feminist theology gave Korean women a wake-up call and inspired them to become motivated and do something.

A specific theology called the "Minjung theology" developed in Korea (see Lee J H 1994:5, 159, 135-162; Choo C Y 1983:73-79; Moon H S 1983:123-137; Ahn B M 1983:138-154; Suh KS 1983:15-37, 38-46). It emerged during the early 1970s. "Minjung" means "ordinary people". Minjung theologians explained that Minjung represents isolated people: the poor, the politically oppressed and the marginalized in society. Jesus is the one who liberates people from economic poverty, social discrimination, cultural prejudice and political oppression. Jesus represents the ordinary person (Minjung). In his lifetime Jesus attempted to liberate people, but was eventually crucified. Minjung theology is in a way similar in purpose and reason to the liberation theology in Latin America and the Dalit theology in India. Just as a feminist theology is purposeful for females, so is Minjung theology for the ordinary citizens of Korea. Korean theology has been developing rapidly because of Minjung theology and feminist theology. However, Minjung theology failed to be concerned with the liberation of women from a patriarchal system. Korean women suffered dual oppression: that of patriarchy as well as the indifference to women of Minjung theology.

Korean feminist theologians attempt to articulate their identity as Korean women and to find their own unique way of theologizing as feminist theologians. Korean people in general have gained an understanding of their situation and try to find solutions in many different ways. 


\section{THE MYTH OF KOREAN ORIGIN}

\subsection{The story of the myth}

This story of Korean origin (see Choi MJ 1990) is told among Koreans from generation to generation. It is part of Korean oral tradition. The myth of Korean origin is the story of "Dankun" which means "a useful person for others far and wide". Korea has a 5000-year-old history. In the very beginning, so the story goes, there were two animals, a tiger and a bear. Both of them came before the heavenly god in the high mountains. Their request was to become human beings. The god told them to eat only garlic and drink water for 100 days in a dark cave with no light. Then they would become human beings. If they left the cave before the 100 days were over, they would lose their only chance of being transformed into humans.

During the first few days in the dark cave with only garlic and water, the two animals were hopeful and able to endure their hunger. After a few days, however, they became tired and hungry, slowly losing their motivation to become human. The tiger began complaining to the god, saying how cruel the god was, how much he missed other food, light, being outside, fresh air and the fields. The tiger went on about how tiresome it was to eat only garlic and how damp and misty the cave was. The bear encouraged the tiger tenderly by telling him that this would last only for a limited time. Then they would change into human beings.

Although the bear consoled the tiger many times, the tiger could not resist the longing for other food and light. The tiger eventually left the cave, the bear continued to think of the future and remained there alone. Finally, the 100 days were over. The god came to the bear and gave a blessing. The bear was transformed into a beautiful woman. Her name was "Woong-yo", meaning "a woman from a bear" or "a bear-woman".

At that time, the god's son came down from the high mountains and fell in love with "Woong-yo" at first sight. With permission from his father he remained with "Woong-yo" on earth instead of returning to the mountains. They were 
married and soon after had a son, the first person in the myth of Korean origin. He was named "Dankun", a useful person for others. He was the first ancestor of Korea.

\subsection{Reflection}

All tribes have their own myths. Concerning the evaluation of myths, Rosemary Radford Ruether (1993:8) says the following:

"Myths" in the sense of exemplary stories, are not illegitimate. Moreover, history is never completely objective, but is always a selection and interpretation of the past to make meaning for the present. But this does not mean that there can be no historical knowledge apart from subjective wishes, nor that myth does not need to be examined for it's spiritual and ethical values.

Myths express people's beliefs and ways of thinking. To understand the Korean myth is, in a sense, to understand the basic thinking of Koreans. This myth originated during the time when animism prevailed in Korea. Ancient society was maternal and women's power was strong. A scholar of Korean literature, A L Lee (1983:24), explains that "Korean characteristics are endurance and tenacity of purpose. Koreans have endured all kinds of problems in difficult situations of international politics, economics and histories, and overcome those situations". Throughout history, Koreans have had many severe, bitter trials and difficulties, some caused by other countries and others within the Korean nation.

Firstly, I would like to comment on the status of women as reflected in this Korean myth. Woong-yo endured her difficulties and gave birth to a son who was the first ancestor of Korea. Through this myth, it is emphasized that women should endure at all times. Since Woong-yo represents all Korean women, the story teaches women to be obedient without complaint. Secondly, after the appearance of Dankun, the son who governed Korea, the mother Woong-yo disappears from the story. Woong-yo was just a supporting actor. So are Korean women. After marriage, women lose their names. Their identity disappears. They become "somebody's wife", "somebody's daughter-in-law", 
"somebody's mother", or "a member of somebody's family". This disappearance indicates that their role is secondary. A woman's role and main function is to have a baby, preferably a son. This belief resulted in Korean women staying at home for a long time. The myth of Korean origin highlights the attitudes often quoted to Korean women as desirable: endurance, obedience, women's invisibility, and women's secondary role.

\section{GASI GOGI (A THORNY FISH)}

\subsection{The story of Gasi Gogi}

Cho's novel (1998) focuses on Daum, a ten-year-old boy, who suffered from leukemia. His father, Jung Ho-Yun is a poet. Remembering his own unfortunate childhood, he strives to be the perfect father. Jung Ho-Yun's father was a coalminer who lost a leg in an accident. Receiving no compensation, he was forced to resign. He threatened his employees with a knife and was thrown into jail. Finally, when he was released from prison, he could not find employment anywhere. Because of the increasing poverty in the family his wife left him. The father lost all hope and suggested to his son, Ho-Yun, that they should eat rat poison and die together. Ho-Yun refused after which his father left him at a police station with a few last words expressing his pessimistic view of life. He was never seen again.

Ho-Yun was moved from orphanage to orphanage. He tried to be accepted, faced much misery, loneliness and pain. He was oppressed by the stereotypes, which the people around him deeply imposed on him, that orphans were the unfortunate, who could never succeed in life. Nevertheless, he made a huge effort, took the opportunities open to him, managed to complete his university courses and became a successful poet. With the status of a poet, Jung Ho-Yun earned himself a wife. She had studied art at the same university. She fell in love with his poetic soul and they got married. Together they had a son whom they named Daum. Daum was the great joy of Ho-Yun's life. Jung Ho-Yun continued to write and publish poems, but his income did not meet his 
wife's expectations, since she came from an affluent background. Hence, after six years of marriage, Ho-Yun's wife demanded a divorce in order to continue with her art studies. This was not possible within the confines of family life. After the divorce, she married an art teacher, twenty years older than herself and they left for France. She sent a letter to her ex-husband saying that she would no longer be responsible for Daum.

Daum's leukaemia was discovered just after the divorce of his parents. He was admitted to hospital, but soon recovered and returned home. Six months later his illness reappeared and he went to hospital for an indefinite period. Daum suffered immensely on account of the radiotherapy, the countless pills and the unsalted food. It was too much for the ten-year-old boy. He decided to record all his feelings and emotions in a diary. These entries, appearing in the novel every now and then, show how his main source of encouragement and guidance to get through the rough days, was his father. Without him he would not have been able to make it. He did, of course, long for a mother just like all his friends in the same room. However he knew that he owed everything to his father.

After two years of treatment, there was no sign of recovery. They were left with only one other possible treatment - a bone-marrow transplant from someone who was compatible with Daum. It was going to be very expensive and cause twice as much pain as Daum had already faced. The father had already sold his house and all their possessions in order to keep Daum in hospital for 2 years. He had suffered much on account of his son, but did so willingly with the hope that his son may be able to recover. He agreed to the transplant in spite of the cost. Their search for a donor was, however, unsuccessful. Hope faded and Ho-Yun requested that his son be released from hospital and all medication stopped since is caused his son so much pain.

A week before his son's release from hospital, Jung Ho-Yun read in the paper that his ex-wife, who had now completed her studies in France, had returned to Korea to hold an art exhibition. Since Daum's future was uncertain, Ho-Yun went to the exhibition to find his ex-wife. He told her of the situation and 
asked her to come and see her son before it was too late. As the day of Daum's release arrived, she still had not come. With their last possessions they managed to buy a car to drive down to the coast, since Daum's final wish was to see the ocean. At the coast they met an old man who lived up in the mountains. He was a herbalist who made and sold potions from medicinal plants which grew in the mountains. The old man, who had had fatal lung disease, had been forced by his illness to seek the fresh mountain air. On account of this coincidental acquaintance Daum and his father went to live in the mountains. After about a month Daum's illness recurred and he had to go back to hospital. There they discovered that the doctor and Ho Yun's ex-wife had been searching for them. The doctor had found a Japanese girl who was a compatible donor. The transplant was now possible, but Daum's father could not possibly afford it. He heard that one could receive a large amount of money for internal organs, so he planned to secretly sell his kidneys to make just enough money for this transplant. When Ho Yun went for a checkup, they discovered that he had severe liver cancer. He was in the last stages of cancer. He would die within a month. During the previous ten years, he had concentrated so much on his son's health that he had not realized what his own health condition was. Now there was no hope. However, his ex-wife, who had given up all her parental rights, decided to share in caring for their son and to pay the hospital bills. The father felt that the best thing he could do for his son before his death, was to keep him under his care until the end. He believed that it was best if he were to get the money together himself.

Secretly he sold the cornea of his one eye and earned just enough for the transplant. The transplant was a success and Daum finally recovered. Then Jung Ho-Yun forced Daum to go away with his mother in order to have a happy life in France. His own sorrow, pain, and suffering were kept secret, because that was best for his son, he believed. Ho-Yun then went to die alone in the mountains where he and his son had spent a peaceful month together. 


\subsection{Feminist critique}

The explanation of the title "a thorny fish" is as follows: Daum is reminded of a thorny fish by the conduct of his father. A thorny fish is one of the small fishes in the sea. The mother fish lays eggs and leaves immediately afterwards. But the father fish, carrying the responsibility of a parent, remains to keep watch over the eggs. When they hatch and the baby fishes grow, they all part and go their own way, leaving the father fish behind. The father fish knows that his job as a father is completed. He then bangs his head on a rock and kills himself. Daum believes that his own father had been just like a thorny fish.

Modern science and technology, the unification of world trade, travel and communication have influenced the rapid changes in Korean society since the 1960s, certain trends in the culture and religion (see Lee HS 1992:45-53). Lifestyles, practices, and relationships have been modernized in the Korean family and society. One reaction to these changes is fundamentalism which manifests in a closing in of culture and religion, a defense of one's privilege against others and attacks on what is different. Capitalism and free enterprise encourage freedom of religion, but support the values of capitalist system. Consumerism is spread through trade, aid, education, and development polices. Its negative effect includes abuses such as drug addiction, prostitution, corruption and the undesirable influence of the mass media. The value of religion is generally exchanged for the greater freedom and material advantages of the system. The world powers through their impact on economic, political, and military issues have an influence on Korea's culture and even on the religious attitudes of Korean people.

Korean society no longer teaches the values of life, values of society, and moral values. Economic growth has become the most precious value, which means that Koreans have become materialists for whom money is the first consideration. Materialism leads to a competitive consciousness: people are driven to desire social success and promotion. Achievement becomes a most important value. Materialism resulted in the conspicuous trend toward nuclear families rather than larger extended families. In the traditional family system, 
children naturally learned the values of life from the many members of the family. However, modernism made people meet in dialogue around basic core values and fundamental inspirations, which contribute powerfully towards integral human liberation and the fulfillment of people.

Since the end of 1980, Koreans have been experiencing postmodernity (Kim AY 1995:224-230; see Choi MJ 1995:103-145) with its loss of respect for authority and its democratization of social, economic and political life. People seem to have lost their objectives. Some Koreans are living in pre-modern, some are in the modern, and some are in the postmodern era. These divergences derive from peculiar historical, cultural, religious, and social factors.

Many things have changed in Korean society. Since "globalzation", Huber (1996:37-39) describes the social changes in 1980s in America. These changes are similar all over the world, including Korea:

- The 1980s changed the individualization of life styles. People no longer lived according to a standardized design, shaped by family or personal conviction. Individualism is prevalent among the younger generation.

- "Public persons" like bishops, leaders of industry or presidents, party leaders or cabinet ministers, pastors or teachers, failed to live up to expectations. As a result, officials lost credibility and popularity. Star athletics and pop musicians are taking the place of "public persons".

- Competitive sport has been interwoven with politics in the past few decades, not only as a means of national self-expression but also as an instrument in the struggle between political systems.

- Another developmental trend is the changes resulting from the shift "from world politics to world economics". The conflicts between political systems now take place on the level of worldwide economic competition.

The context of the story of the thorny fish is the 1990s. At that time fathers lost their absolute position and rights in society. The image of a father as dictator 
and absolute monarch respected and obeyed by children which prevailed until the 1970s, was lost. Fathers lost their prestige and authority. This reflects the postmodern denial of the "absolute". Another factor was that most fathers were working very hard at the working places. This meant that children could not see their fathers during the daytime or at home. The father was seen as the "money maker" or "money machine". The role of the father in the home has become weaker since the Korean industrial development. The mother, on the other hand, now often organizes the finances of the family. She provides for the family's needs. During the 1990s, many wives, who were not fulfilled by their husbands, left them. This has become a big social issue. The author tried to replace the fathers' authority and powerful position with the quality of caring for their children. In this way the author transcended the traditional ideas about the role of male.

Here, it is necessary to study "God the Father" in contemporary culture and theology. According to Hamerton-Kelly (1979:Forward) "a near century of psycho-analytic research and reflection on the cultural importance of traditional symbols has shown that the term 'father' is both more significant and often more problematic than prior generations explicitly realized". God the Father seems to judge Israel and is to be feared in the Old Testament. People's initial preconception of God is contradictory to a surface reading of the biblical texts. God, as portrayed in a patriarchal setting, is not credible to postmodern people.

Freud's insistence on the Father's centrality in human consciousness should be seriously challenged, because the figure of God the Father is a reflection on the place of the father in people's cultural heritage (Hamerton-Kelly 1979:5). Mary Daly's opinion about God's image as father is expressed in her book Beyond God the Father. She sees the father image as the cornerstone of a self-alienating mode of existence, which produces rape, genocide, and war. When the father-God and his works are renounced, a new heaven and earth of mutual respect, truth, and vitality will come about. She argues for symbolization which is not anthropomorphic: "... neither the Father, nor the Son, nor the mother is God (God is) the Verb who transcends anthropomorphic symbolization" (Daly 1973). She argues that a re-visioning of God must focus on the experiences of 
becoming, rather than the sense of structure and permanence. Mary Daly analyzes societies in which patriarchy was and is the root of all evil. However, there are many other factors for the analysis of the roots of societies: the individual's perversity, the love of death and destruction that disturbs all attempts to organize human beings for goodness. Daly's (1973:6) challenge is that "the patriarchal shape of Judaism and Christianity has contributed mightily to the ills which these religions are committed to relieve; that the religious are, in short, self-contradictory; and that this is caused by their devotion to the symbol of "father" for God". Her promise is that when women move beyond the father symbol, women shall enter new realms of energy and possibilities for human happiness (Daly 1973:6). To share in God's blessing, one had to belong to a family, so the status of the father was divinely sanctioned, and the divinity was involved in the history of the individual and society at the most intimate level - the level of family. From the history of the god conceptions, earthly fatherhood was seen as the source of life and the guarantor of order in the family. God was associated with the experience of sustenance and education from the history of fatherhood in Israel (Daly 1973:27; see De Boer 1974:966-969). Israel was a patriarchal society, which was organized into families, tribes, and clans according to patrilineal relationships. A family was called "the house of the father" and usually composed of three generations. It was essential to be buried with the father, to remain within the sphere of the family blessing. Therefore, the father's power was absolute in the family.

In the Old Testament, God is depicted as Savior (Ex 3:7-8), as a sincere God (Ps 146:6), as an almighty God (Gn 17:1; Ps 91:1), a fearful God (Jr 5:24; Ec12:13), as a warrior (Jr 20:11), as a wise God (Job 12:13), as a judge (Is 33:22), as The Holy One (Hs 11:9), as the creator (Is 40:28; Dt 33:27), and as God the Father (Ps 89:26; Jr 3:19; Is 64:8; Ps 68:5). The Israel God is expressed in many ways. God is also portrayed by means of imagery of mother or woman: 
The Lord God made garments of skin for Adam and his wife and clothed them (Gn 3:21).

He shielded him and cared for him; he guarded him as the apple of his eye (Dt 32:10).

You deserted the Rock, who fathered you;

You forgot the God who gave you birth (Dt 32:18).

keep me as the apple of your eye; hidden me in the shadow of your wings (Ps 17:8).

I cry out the God Most High, to God, who fulfills his purpose for me (Ps 57:2).

Because you are my help, I sing in the shadow of your wings (Ps 63:7).

He will cover you with his feathers, and under his wings you will find refuge;

his faithfulness will be your shield and rampart (Ps 91:4).

But I have stilled and quietened my soul;

like a weaned child with its mother, like a weaned child is my soul within me (Ps 131:2).

But now, like a woman in childbirth, I cry out, I grasp and pant (Is 42:14).

Listen to me, O house of Jacob, all you who remain of the house of Israel, you whom I have upheld since you were conceived, and have carried since your birth.

Even to your old age and gray hairs I am he, I am he who will sustain you. I have made you and I will carry you; I will sustain you and I will rescue you (Is 46:3-4).

Can a woman forget the baby at her breast and have no compassion on the child She has born? Though she may forget, I will not forget you! (Is 49:15) 
This is what the Lord says:

"A voice is heard in Ramah,

mourning and great weeping,

Rachel weeping for her children

and refusing to be comforted,

because her children are no more." (Jer 31:15)?

This what the Lord says:

"Restrain your voice from weeping

and your eyes from tears,

for your work will be rewarded,"

declares the Lord (Jr 31:15-16).

I will extend peace to her like a river,

and the wealth of nations like a flooding stream;

you will nurse and be carried on her arm

and dandled on her knees.

As a mother comforts her child,

so will I comfort you;

And you will be comforted over Jerusalem" (Is 66:12-13).

When Israel was a child, I loved him, and out of Egypt I called my son.

But the more I called Israel

the further they went from me.

They sacrificed to the Baals

and they burned incense to images.

It was I who taught Ephraim to walk,

taking them by the arms;

But they did not realize

it was I who healed them.

I led them with cords of human kindness,

with ties of love;

I lifted the yoke from their neck

and bent down to feed them (Hs 11:1-4).

The use of female sexual imagery of God in Hosea is illuminated by feminist theoretical considerations. According to Setel (1985:95) "a central issue for contemporary religious feminists is the extent to which the use of these (and other) biblical writings continues to so define women in our own societies". The passages of the female features of God acknowledge female experience and allow women to redefine the relationship between God and women. 
There was a serious ambivalence in the early Christian attitude towards the authority of the father. It is most evident in the sayings about the status of women, which express contempt (I Cor 14:34) and sometimes unparalleled affirmation (Gal 3:28). This situation represents the confrontation between the impulse for reformation of patriarchy on the one hand, of which Jesus is an example, and the resistance of entrenched privilege on the other. Jesus broke the forms of the patriarchal family in the name of God the Father, and recognized the natural right of women to equal humanity with men. Jesus had women in his entourage (Mk 15:40-41). Jesus spoke with women in public (Jn 4:27). Jesus spent time teaching them (Lk 10:39). Jesus let a woman wash his feet, and let her perform a service for him, which was a sign of the characteristic of a wife's duty for her husband (Lk 7:36-38). Jesus paid special attention to mothers and children, regardless of the characteristic objections from his disciples (Mk 10:1316). Jesus refused to condemn an adulteress, knowing how unfair the law on adultery was to women, upon whom alone it laid the obligation of absolute marital fidelity (Jn 7:53-8:11). Jesus allows neither the subordination of one partner to the other, nor the treating of women as a chattel, whose adultery infringes the man's property rights. Jesus seems to reject patriarchy - the absolute authority.

Women were required to give up their individual profession for the sake of the traditional woman's role of keeping peace in the family. Daum's mother has a different opinion. She breaks away from this idea; she wants to study her paintings more. The mother tries to establish her own position in the society. She seems to be a liberated woman. But she is portrayed as the opposite of the traditional model of a wife and a mother. Whenever she wants to do something, she does. Whatever she wants to say, she says. The author highlights the father as a positive model. He describes the mother in a more negative way. She leaves her family because of the poor conditions; she gives up the right of nurturing her child when she divorces; she is portrayed as careless, unkind and unfaithful. She is influenced by financial circumstances. She seems to be constantly changing her mind, depending on what the advantages are for her; she first gives up her responsibility for her child but later wants to help him. 
Daum's father is portrayed as mild, gentle and nice. He is attentive and considerate towards his son. The mother is not prepared to endure pain and seems to act on impulse. She does not consider the situations and feelings of others. The author expresses dualistic notions, one of which is good, and the other is not. Daum's father cares for his son very well without a wife. Readers can feel the betrayal of Daum's mother, because she does not act as a traditional mother. Therefore, the author's intention seems to be to lead the readers to trust and have confidence in Daum's father rather than in the mother.

The story seems to indicate that one who has money and power can have the child too. The powerful person (Daum's mother) continually maintains power, but the powerless person (Daum's father) seems unable to overcome his difficulties. She suddenly demands a divorce, without consideration of what the husband and her child are going through. The husband must endure many things: loneliness, abandonment, an unsatisfactory job and financial problems, his son's bitter suffering, the lack of proper treatment for his son, the pain and anguish of his incapability to be of any help to his son. Even though Daum's father is male, his actions are like those of a female in traditional and current times. The author tries to describe the good father, but he has placed the male and the female in opposition. That is, the patriarchal power game is depicted in the story, the only difference being that the roles related to gender, are reversed.

Some incentives for social reformation can be found in the story.

- Daum's mother tries to liberate herself from her circumstances.

- Traditional roles of male and female should be changed. A father also has the responsibility to care for children. Daum's father cares for his child very well. This challenges many Korean men as fathers. The author breaks through the traditional thinking about the male and female role in the story.

The father, Chung Ho-Yun, spoke to his son in his mind as he was dying, "I am not going to be dead eternally, even though I have died. I will be living in you, whom I have left behind in the world. You can see, hear and touch me, because 
I will be walking with you forever. As I always accompany you, I worry that you may fall down, be tired, or stop walking." The son, Daum, was to be a successor of his father. Herein the meaning of resurrection can be seen. The successor is important to the minds of Oriental people, because the old generations have to die but the new generation can live on with their images and passion. A female model in Confucianism is "motherhood", which means that a mother must bear a son as the successor of paternity. Only after having given birth to a boy, is a woman recognized as a "human being". This idea is still ingrained in women today. They still want to obtain a firm position in the family, irrespective of how educated they are. A Korean female novelist asks, "Is it natural for today's women to try in so many ways to have a son?" (Lee NH 1996:188).

When Ho-Yun surrenders all hope, he enters the hospital chapel. He is anxious for the recovery of his son, therefore he begs the Absolute Being to give his son back his life. He is prepared to give his own life in his son's place. He is not a Christian so he does not know who the Absolute Being is in whom his son, Daum believes. Christ can be imaged through Ho-Yun who gives his body for his son.

Through Ho-Yun's prayer, Korean mothers who have prayed for their children and families can be recognized. An ancient ritual from the oral tradition is upheld when a woman blesses herself and her family. It is very private selfaffirmation for Korean women. I believe that those wishes and blessings keep Korean families and society well.

\section{POSITIVE THINKING}

Women did act in society and tried to discover their potential. Through women's experiences, the texts which keep women in an inferior position can be analyzed and criticized. According to Song, Choan-Seng (1982:14) "women in many parts of the world are searching for a new image of women in the human community dominated for centuries by patriarchal systems and male-centered social structures". Positive insight, positive thinking, positive perspective, and positive actions can be utilized by Korean women for the sake of women's liberation. 


\section{Works consulted}

Ahn, B M 1983. Jesus and the Minjung in the Gospel of Mark, in Minjung theology: People as the subjects of history, ed by The Commission Theological Concerns of The Christian Conferences of Asia, 138-154. Maryknoll, NY: Orbis Books.

Ahn S Y 1992. Feminist theology. Seoul: Korean Christian Press.

Cho, C I 1998. Gasi Gogi. Seoul: Bal-Eun Sey Sang.

Choi, M J 1987. Feminist christology. Manila: Consultation on Asian Women's Theology.

Choi, M J 1990. Feminist theological interpretation of Korean shamanism, in Religious pluralism and theological tasks. Seoul: Korean Christian Press.

Choi M J 1991. Sexism in Korean history, in Participation in feminist theology: The Book of Feminist Theologians' Association in Korea, 217-227. Seoul: Korean Christian Press.

Choi, M J 1995. Introduction (Interpretation of the Bible from Korean Women's perspective), in The Bible and feminist theology, Vol 2: The Book of Feminist Theologians' Association in Korea, 103-145. Seoul: Korean Christian Press.

Choo, C Y 1983. A brief sketch of Korean Christian history from the Minjung perspective, in Minjung Theology: People as the subjects of history, ed by The Commission on Theological Concerns of The Christian Conferences of Asia, 7379. Maryknoll, NY: Orbis Books.

Chung, H K 1990. Struggle to be the sun again: Introducing Asian women's theology. London: SCM.

Daly, M 1973. Beyond God the Father: Toward a philosophy of women's liberation. Boston, MA: Beacon.

De Boer, P A H 1974. Fatherhood and motherhood in Israelite and Judean piety. Leiden: Brill.

Hamerton-Keller, R 1979. God the Father: Theology and patriarchy in the teaching of Jesus. Philadelphia, PA: Fortress.

Heine, S 1988. Christianity and the goddesses: Can Christianity cope with sexuality? London: SCM.

Huber, W 1996. Violence: The unrelenting assault on human dignity, tr by R C L Gritsch. Minneapolis, MN: Fortress.

Isherwood, L \& McEwan, D 2001. Introducing feminist theology. Sheffield: Sheffield University Press.

Kim, A Y 1995. The horizon of Korean feminist theology. Seoul: Hanwool Press. 
Kim, J H 1996. A voice from "the borderlands": Asian-American women and their families, in A Carr \& M Leeuwen (eds), Religion, feminism, \& the family, 344-357. Louisville, KY: Westminster.

Kim, Y O 1988. The biblical study for women liberation. Seoul: Theological Institution. Lee, A L 1983. The Korean literature. Seoul: Ee-Mun-Kak.

Lee, E S 1989. Women and Jesus, in Journal of Christianity (Ki Dok Kyu Sasang), December 1989, 176-192.

Lee, E S 1991. Feminist theology and christology, in Journal of Christianity, May 1991, 33-51.

Lee, H S 1992. 25 years history of women's union in Korean church. Seoul: Union of Christian Women in Korea.

Lee, J H 1994. The exploration of the inner wounds-han. Atlantia, GA: Scholars Press. Lee, K S 1991. Sexism and advocacy for women in the Old Testament. Journal of Christianity, May 1991, 7-18.

Lee, N H 1996. Forty years old in her novel. Seoul: Creation and Analysis Press. Lee, O J 1983. Jesus, women, and Minjung. Seoul: Korea Theological seminary Press. Lee, O J 1985. Theology for women. Seoul: Han Kuk Younkuso.

Lee, O J 1987. Understanding of feminist theology. Seoul: Women Department in NCC. Lee, O J 1988. Awaken! Women! Seoul: Hak Min Sa.

Lim, H S 1991. New women and new church, in Participation in feminist theology: The Book of Feminist Theologians' Association in Korea, 274-284. Seoul: Korean Christian Press.

Moltmann J \& Moltmann-Wendel, E 1991. God - his and her. London: SCM.

Moon, H S 1983. An Old Testament understanding of Minjung, in Minjung theology: People as the subjects of history, ed by The Commission on Theological Concerns of The Christian Conferences of Asia, 123-137. Maryknoll, NY: Orbis Books.

Park, S K 1983. The tasks of women's theology in Korea. Seoul: Hyundai Shinsuh. Ruether, R R 1979. Mary: The feminine face of the church. London: SCM.

Reuther, R R 1985. Women-Church: Theology and practice of feminist liturgical communities. San Francisco, CA: Harper \& Row.

Ruether, R R 1993. Gaia and God: An ecofeminist theology of earth healing. London: SCM.

Russell, L 1982. Becoming human. Philadelphia, PA: The Westminster Press.

Russell, $L$ 1985. Authority and the challenge of feminist interpretation, in Feminist interpretation of the Bible, 137-146. Oxford: Blackwell.

Schüssler Fiorenza, E S 1981. Bread not stone. Maryknoll, NY: Orbis Books. 
Setel, T D 1985. Prophets and pornography: Female sexual imagery in Hosea, in L Russell (ed), Feminist interpretation of the Bible, 86-95. Oxford: Basil Blackwell.

Sharma, A (ed) 1994. Today's woman in world religions. New York, NY: State University of New York Press.

Song, H S [1982] 1989. A woman worker's field report: The industrial mission, in A Boesak (ed), Testimonies of faith in Korea, 196-200. World Alliance of Reformed Churches (WARC).

Suh, K S 1983. A biographical sketch of an Asian theological consultation, in Minjung theology: People as the subjects of history, ed by Commission on Theological Concerns of The Christian Conferences of Asia, 15-37, 38-46. Maryknoll, NY: Orbis Books.

Trible, P 1984. Texts of terror: Literary-feminist readings of biblical narratives. Philadelphia, PA; Minneapolis, MN: Fortress. 